\title{
Into the Mussa Puzzle: Monetary Policy Regimes and the Real Exchange Rate in a Small Open Economy*
}

\author{
Tommaso Monacelli \\ Boston College
}

September 2000

\begin{abstract}
Industrial countries moving from fixed to floating exchange rate regimes experience dramatic rises in the variability of the real exchange rate. This evidence, forcefully documented by Mussa (1986), is a puzzle to the extent that it is hard to reconcile with the assumption of flexible prices. This paper lays out a business cycle model of a small open economy that combines nominal rigidities with a systematic behavior of monetary policy approximating a continuum of exchange rate regimes. The model is consistent with Mussa's findings: in the simulations the real exchange rate is between four and five times more variable under floating than under fixed rates. Most importantly, this holds independently of the underlying source of fluctuations in the economy, stressing the role of the nominal exchange rate regime per se in affecting the variability of the real exchange rate. The paper also sheds light on the sign of the international transmission of shocks under endogenous monetary policy.

Keywords: real exchange rate, sticky prices, endogenous monetary policy.

JEL Classification Number: E52, E32, F41

${ }^{*}$ This paper is a revised version of chapter 1 of my Ph.D. dissertation at New York University. I am indebted to Jordi Galí and Mark Gertler for suggestions and many useful discussions. I also thank Pierpaolo Benigno, Raquel Fernandez, Bojan Jovanovic, Robert Kollmann, Giorgio Topa, Andres Velasco and seminar participants at Bank of England, Bocconi University, Boston College,CEMFI, Columbia University, European Central Bank, Federal Reserve Bank of New York, GWU, IIES Stockholm, INSEAD, NYU for comments. I am, of course, the only responsible for all remaining errors. Please address correspondence to: Department of Economics, Boston College Carney Hall, Chestnut Hill, MA 02467-3806. Tel: 617-552-3690, Fax: 617-552-2308, E-mail: monacelt@bc.edu.
\end{abstract}




\section{Introduction}

For a long time, economists have debated about whether fluctuations in the exchange rates reflect mere changes in relative money prices, as opposed to changes in the relative prices of goods or inputs. In a very influential paper, Mussa ${ }^{1}$ forcefully documents two facts: i) nominal and real exchange rates are strongly correlated; ii) industrial countries moving from fixed to floating exchange rate regimes experience dramatic rises in the variability of the real exchange rate. In Figure 1, the D.Mark-US dollar nominal and real exchange rates (top panel), the short-run variations of the real exchange rate (medium) and of its components (bottom) are plotted. The evidence is striking. The nominal exchange rate $i s$ actually the real rate. A spectacular increase in volatility stands out in the post-Bretton-Woods era for both the real and the nominal exchange rate, as opposed to a noticeably constant variability of the price level ratio. The statistics reported in Table 1 for three selected OECD countries confirm this fact. The standard deviation of the real exchange rate is between three and five times higher under floating rates. The standard deviation of the foreign-to-domestic price ratio barely changes. The correlation between nominal and real exchange rate is close to unity, and tends to decrease in shifting to fixed exchange rates. Overall, the movements of the nominal exchange rate play a dominant role in shaping the short-run variations of the real exchange rate. According to Mussa, these regularities systematically apply to every postwar exchange rate regime shift by an industrial country ${ }^{2}$.

At this point, it might seem that little room remains to argue that the exchange rates are a purely nominal phenomenon. Why, then, has this evidence often been treated as a puzzle? Consider, first, the high correlation between nominal and real exchange rate. This is hard to reconcile with models of flexible output prices. In the case of perfectly fixed prices, in fact, the correlation would be exactly one, and would decrease with a higher price flexibility. The strong comovement between nominal and real exchange rate, however, might still be consistent with a flexible-price model in the presence of a high incidence of real shocks, i.e., shocks originating in the goods market that require adjustments of the relative prices ${ }^{3}$. Yet this would not explain why the volatility of the real exchange rate systematically starts to increase after switching from a regime of fixed to one of floating rates, i.e., it would be inconsistent with the second regularity reported above. It could also be argued that the choice of the exchange rate regime is endogenous, and that it is indeed those countries experiencing large real shocks that switch to floating exchange rates ${ }^{4}$. The evidence on the change in volatility, 
however, is so overwhelming and extended over time that this does not seem a plausible explanation ${ }^{5}$. Nor can the whole evidence be rationalized in purely real models of the international business cycle, like the ones pioneered by the work of Backus-Kehoe-Kydland (1992), in which a switch in the exchange rate regime is simply not addressable.

In this paper, I lay out a dynamic general equilibrium model of a small open economy characterized by two main features. The first one is a certain rigidity in the adjustment of prices, in accordance with Figure 1. The second one is the commitment to (monetary) policies consistent with the maintenance of managed-fixed nominal exchange rates. This systematic component in policy stands in contrast with the supposed role of stochastic (real) shocks in explaining the change in variability of the real exchange rate after a switch in regime.

I show that a model combining these two main features accords well with the empirical evidence reported in Table 1: in the simulations, the real exchange rate is between four and five times more variable under floating than under fixed rates; the correlation between nominal and real exchange rate is close to one under floating, and tends to decrease under fixed rates. Most importantly, these results hold independently of the underlying source of fluctuations, casting doubts on the theory that stresses the prominent role of real shocks.

A central goal of this paper is to link the international finance literature on sticky-price models of the exchange rate with the recent one on monetary policy rules emphasizing the systematic behavior of monetary policy in shaping the business cycle. The latter one has made contributions almost entirely confined to the closed economy ${ }^{6}$. In an open economy context, however, where exchange rate regimes matter, it seems even more appropriate to think of monetary policy in terms of endogenous rules. A novelty of the model lies, in fact, in the representation of a managed-fixed exchange rate regime by means of an interest rate rule assigning an increasing weight to the deviations of the nominal exchange rate from a theoretical parity. In this context I show that a monotonic inverse relation exists between the "degree of proximity" to a fixed exchange rate regime (measured by the weight assigned to the nominal exchange rate in the interest rate rule) and the volatility of the real exchange rate.

\subsection{Related Literature}

Recently several papers, both empirical and theoretical, have tried to address the related but distinct issue of the large and persistent deviations of the 
real exchange rate from the purchasing power parity (the "PPP puzzle") ${ }^{7}$. The dramatic short-term volatility of the real exchange rate observed in the data after Bretton-Woods seems hard to reconcile with the very low rate at which the deviations from PPP tend to die out. The former feature, along with the evidence of sluggishness in the adjustment of prices, calls for a role of nominal-monetary shocks. The latter one, along with the evidence of a unit root in the real exchange rate process ${ }^{8}$, suggests a significant influence of real (demand and/or supply) shocks with a large permanent component. Clarida-Galí (1994) find support for the hypothesis that monetary shocks can account for a substantial fraction of the variance in forecasting the level of the real exchange rate, but only for two out of four case studies considered $^{9}$. This suggests that both real and monetary shocks may be important in order to explain the short-run movements of the real exchange rate. The need of both types of disturbances may explain why a more recent series of theoretical papers based on the effects of monetary shocks alone have proved to be inadequate in addressing the PPP puzzle. These papers include Beaudry-Deveraux (1995), Chari-Kehoe-McGrattan (2000), Kollmann (1997), Betts-Deveraux (2000), among others. This literature, however, deals solely with the problem of explaining the absolute level of the real exchange rate volatility. My work focuses on the systematically different behavior of the real exchange rate across regimes. I claim that this is a regularity that can be more accurately addressed on the basis of a structural model, in particular one characterized by sluggishness in the adjustment of prices.

The remainder of the paper is as follows. Section 2 presents an equilibrium optimizing model of a small open economy where the systematic behavior of monetary policy is critical in defining the features of the exchange rate regime. Section 3 describes the parametrization applied to the simulations. Section 4 discusses the main findings on the relationship between real exchange rate and monetary policy regime, and the role of nominal rigidities. Section 5 explores the impact of the exchange rate regime on the business cycle fluctuations. Section 6 concludes.

\section{The Model Economy}

Consider a small open economy populated by identical, infinitely lived house-

holds. Consumers yield utility from real consumption, leisure and demand of real money balances. The real consumption index $C_{t}$ is a CES aggregate of $C_{H}$ and $C_{F}$, where $C_{H}=\left(\int_{0}^{1} C_{H}(i)^{\frac{\vartheta-1}{\vartheta}} d i\right)^{\frac{\vartheta}{\vartheta-1}}$ and $C_{F}=\left(\int_{0}^{1} C_{F}(i)^{\frac{\vartheta-1}{\vartheta}} d i\right)^{\frac{\vartheta}{\vartheta-1}}$ 
represent composite indexes of domestic and foreign (imported) goods, respectively. Both goods are tradeable. In the following, I assume $\vartheta>1$.

Therefore:

$$
C_{t}=C\left(C^{H}, C^{F}\right)=\left(\gamma^{\frac{1}{\rho}}\left(C_{t}^{H}\right)^{\frac{\rho-1}{\rho}}+(1-\gamma)^{\frac{1}{\rho}}\left(C_{t}^{F}\right)^{\frac{\rho-1}{\rho}}\right)^{\frac{\varrho}{\varrho-1}}
$$

where $\gamma \in[0,1]$ is the share of home-produced goods in total consumption and $\varrho>1$ is the elasticity of substitution between domestic and foreign goods.

Define $P^{H}=\left(\int_{0}^{1} P^{H}(i)^{1-\vartheta} d i\right)^{\frac{1}{1-\vartheta}}$ and $P^{F}=\left(\int_{0}^{1} P^{F}(i)^{1-\vartheta} d i\right)^{\frac{1}{1-\vartheta}}$ as the associated utility-based price indexes, both expressed in units of the domestic currency. I assume that the law of one price holds, so that $P_{F}(i)=$ $e P^{F^{*}}(i)$. Accordingly, an aggregate utility-based domestic price index can be defined as:

$$
P_{t}=\left(\gamma\left(P_{t}^{H}\right)^{1-\varrho}+(1-\gamma)\left(P_{t}^{F}\right)^{1-\varrho}\right)^{\frac{1}{1-\varrho}}
$$

The intertemporal problem of the generic household can be written:

$$
\max E_{t} \sum_{t=0}^{\infty} \beta^{t} \zeta_{t} U\left\{C_{t}, N_{t}\right\}
$$

subject to the following sequence of budget constraints (expressed in units of domestic currency):

$$
\int_{0}^{1}\left[P_{t}^{H}(i) C_{t}^{H}(i)+P_{t}^{F}(i) C_{t}^{F}(i)\right] d i+v_{t, t+1} B_{t}+e_{t} v_{t, t+1}^{*} B_{t}^{*}=W_{t} N_{t}+B_{t-1}+e_{t} B_{t-1}^{*}+\tau_{t}
$$

In the specification above $\zeta_{t}$ is a demand/preference shock.

Optimal allocation of expenditure between domestic and foreign goods yields typical isoelastic consumption demands:

$$
\begin{gathered}
C_{t}^{H}=\gamma\left(\frac{P_{t}^{H}}{P_{t}}\right)^{-\rho} C_{t} \\
C_{t}^{F}=(1-\gamma)\left(\frac{P_{t}^{F}}{P_{t}}\right)^{-\rho} C_{t}
\end{gathered}
$$

By considering the optimality conditions above the intertemporal budget constraint can be written:

$$
P_{t} C_{t}+v_{t, t+1} B_{t}+e_{t} v_{t, t+1}^{*} B_{t}^{*}=W_{t} N_{t}+B_{t-1}+e_{t} B_{t-1}^{*}+\tau_{t}
$$


In Equation (5), $v_{t, t+1}\left(v_{t, t+1}^{*}\right)$ is the price, as of time t, of a riskless nominal bond $B\left(B^{*}\right)$ denominated in domestic (foreign) currency, yielding a nominal return $i_{t}\left(i_{t}^{*}\right)$ in $t+1, W$ is the nominal wage and $\tau$ are lump-sum transfers. The system of FONCs for the household's problem is given by :

$$
\begin{gathered}
U_{t}^{C} W_{t}=-U_{t}^{N} \\
\zeta_{t} U_{t}^{C}=\left(1+i_{t}\right) \beta E_{t}\left\{\zeta_{t+1} U_{t+1}^{C} \frac{P_{t}}{P_{t+1}}\right\} \\
\zeta_{t} U_{t}^{C}=\left(1+i_{t}^{*}\right) \beta E_{t}\left\{\zeta_{t+1} U_{t+1}^{C} \frac{P_{t}}{P_{t+1}} \frac{e_{t+1}}{e_{t}}\right\}
\end{gathered}
$$

where $U^{h}$ is the partial derivative of utility with respect to variable $h$. In the equations above, I have used $\frac{1-v_{t, t+1}}{v_{t, t+1}}=i_{t}, \frac{1-v_{t, t+1}^{*}}{v_{t, t+1}^{*}}=i_{t}^{*}$. Equation 6 governs the consumption leisure trade-off. Equations 7 and 8 are the efficiency conditions for the holding of domestic and foreign bonds respectively.

By combining equation (7) and (8), I can derive the following arbitrage condition under uncertainty:

$$
E_{t}\left\{U_{t+1}^{C} \frac{P_{t}}{P_{t+1}}\left[\left(1+i_{t}\right)-\left(1+i_{t}^{*}\right) \frac{e_{t+1}}{e_{t}}\right]\right\}=0
$$

Equation (9) states that, in equilibrium, the expected differential between the ex-post real returns on the two nominal assets must be zero.

\subsubsection{Foreign consumption demand}

Foreign demand for good $i$ is given by:

$$
C_{t}^{H^{*}}(i)=\left(\frac{P_{t}^{H^{*}}(i)}{P_{t}^{H^{*}}}\right)^{-\vartheta} C_{t}^{H^{*}}=\left(\frac{P_{t}^{H}(i)}{P_{t}^{H}}\right)^{-\vartheta} C_{t}^{H^{*}}
$$

where

$$
C_{t}^{H^{*}}=\left(\frac{P_{t}^{H^{*}}}{P_{t}^{*}}\right)^{-\rho} C_{t}^{*}
$$

in analogy to equation 3 . 


\subsubsection{Domestic Firms}

Domestic firms operate a CRS technology $F(A, K, N)$, where $A$ is a total factor productivity shifter. The nature of the production technology implies that $U C_{t} \equiv$ unit cost $=M C_{t} \equiv$ nominal marginal cost. It useful to think of domestic firms as divided into three units: i) a production unit; ii) an investment unit, and iii) a pricing unit. Investment and pricing decisions are subject to adjustment costs and therefore imply a forward-looking behavior.

\section{A. Production}

The production unit chooses factor demands in a perfectly competitive fashion, taking the level of output as given. Static efficiency conditions for the choice of capital and labor demands are respectively:

$$
\begin{gathered}
m c_{t}(i) \frac{\partial F\left(A_{t}, K_{t}(i), N_{t}(i)\right)}{\partial K_{t}(i)}=Z_{t} \\
m c_{t}(i) \frac{\partial F\left(A_{t}, K_{t}(i), N_{t}(i)\right)}{\partial N_{t}(i)}=\frac{W_{t}}{P_{t}^{H}}
\end{gathered}
$$

where $Z_{t}$ is the real rental cost of capital and $m c$ is the real marginal cost.

\section{B. Investment}

Capital accumulation evolves according to:

$$
K_{t+1}(i)=K_{t}(i)(1-\delta)+\Phi\left(\frac{X_{t}(i)}{K_{t}(i)}\right) K_{t}(i)
$$

The presence of the function $\Phi($.$) , increasing and convex, reflects the$ fact that $X_{t}(i)$ units of investment translate only into $\Phi()$ units of additional capital. The representative investment unit chooses a sequence for $X_{t}(i)$ and $K_{t}(i)$ to maximize its present discounted value given the rental price $Z_{t}$ and the replacement cost of capital (which is normalized to one):

$$
E_{t}\left\{\sum_{k=0}^{\infty} \beta^{k}\left[Y_{t+k}(i)-\frac{W_{t+k}}{P_{t+k}^{H}}-X_{t+k}(i)\right]\right\}
$$

subject to 14 and to the production technology. This leads to the following pair of efficiency conditions:

$$
Q_{t}=\Phi^{\prime}\left(\frac{X_{t}(i)}{K_{t}(i)}\right)^{-1}
$$




$$
Q_{t}=\beta E_{t}\left\{Z_{t+1}+Q_{t+1}\left[1-\delta+\Phi\left(\frac{X_{t}(i)}{K_{t}(i)}\right)-\frac{X_{t}(i)}{K_{t}(i)} \Phi^{\prime}\left(\frac{X_{t}(i)}{K_{t}(i)}\right)\right]\right\}
$$

where $Q_{t} \equiv \beta E_{t} V^{\prime}\left(., K_{t}(i)\right)$, and $V\left(K_{t}\right)$ is the (indirect) value of holding capital stock $K_{t}$. Equations 16 determines the investment rate as a function of the Tobin's q, while equation 17 determines the evolution of $Q$ over time. I assume that in steady state there are no average nor marginal costs of adjustment. Therefore $\Phi\left(\right.$.) is s.t $\bar{Q}=\Phi^{\prime}\left(\frac{X}{K}\right)^{-1}=1$, and $\Phi\left(\frac{X}{K}\right)=\delta=\frac{X}{K}$.

\section{Pricing}

Pricing units are allowed to reset prices according to a stochastic timedependent rule, which implies receiving a price signal at a constant random rate $\phi$ (Calvo 1983). Let $\phi^{k}$ be the probability that the price set at time $t$ will still hold at time $t+k$. The foreign-market price of the domestic good is flexible, and determined by the law of one price. This implies that domestic firm $i$ which is allowed to reset its price will choose $P_{t}^{H}(i)=e P_{t}^{H^{*}}(i)$ to maximize:

$$
E_{t} \sum_{k=0}^{\infty}(\beta \phi)^{k} \Lambda_{t, t+k}\left\{\left[P_{t}^{H}(i)-M C_{t+k}\right] Y_{t+k}(i)\right\}
$$

subject to

$$
Y_{t+k}(i) \leq\left(\frac{P_{t}^{H}(i)}{P_{t+k}^{H}}\right)^{-\vartheta}\left[C_{t}^{H}+C_{t}^{H^{*}}\right]
$$

where $\Lambda_{t, t+k}$ is a marginal utility based discount factor.

The FONC of this problem is given by:

$$
E_{t} \sum_{k=0}^{\infty}(\beta \phi)^{k} \Lambda_{t, t+k}\left\{Y_{t+k}(i)+\left(P_{t}^{H}(i)-M C_{t+k}(i)\right) \frac{\partial Y_{t+k}(i)}{\partial P_{t}^{H}(i)}\right\}=0
$$

Rearranging, the optimal pricing condition reads:

$$
\widetilde{P_{t}^{H}}(i)=\frac{\vartheta}{(\vartheta-1)} \frac{E_{t} \sum_{k=0}^{\infty} \beta^{k} \Lambda_{t, t+k} \phi^{k}\left\{M C_{t+k}(i) Y_{t+k}(i)\right\}}{\left.E_{t} \sum_{k=0}^{\infty} \beta^{k} \Lambda_{t, t+k} \phi^{k} Y_{t+k}(i)\right\}}
$$

Notice that (19) can be interpreted as a dynamic markup equation. Firms forecast (in a discounted manner) future demand and marginal costs in setting the actual price. In the case $\phi=0$ it reduces to the flexible-price 
static condition under monopolistic competition $\widetilde{P}_{t}^{H}=\frac{\vartheta}{\vartheta-1} M C_{t}$, which simply states that firms set prices as a constant markup over nominal marginal costs or, put differently, that real marginal costs are constant.

Given the pricing rule above, in a symmetric equilibrium where the law of large numbers holds, the domestic aggregate price index evolves according to:

$$
P_{t}^{H}=\left[\phi\left(P_{t-1}^{H}\right)^{1-\vartheta}+(1-\phi)\left(\tilde{P}_{t}^{H}\right)^{1-\vartheta}\right]^{\frac{1}{1-\vartheta}}
$$

\subsection{Terms of Trade and Real Exchange Rate}

Finally, the terms of trade is defined as the price of imported goods relative to domestic ones:

$$
S_{t} \equiv \frac{P_{t}^{F}}{P_{t}^{H}}=\frac{e_{t} P_{t}^{F^{*}}}{P_{t}^{H}}
$$

and the real exchange rate as:

$$
e_{t}^{r} \equiv \frac{e_{t} P_{t}^{*}}{P_{t}}
$$

Let's assume that the share of domestic goods consumed by the rest of the world is negligible and that foreign inflation is zero. In this case $P_{t}^{F^{*}}=P_{t}^{*}$. A log-linear approximation of (21), (22) and (2) leads to $\widehat{S}_{t}=$ $\widehat{e}_{t}-\widehat{P}_{t}^{H}$ and $\widehat{e}_{t}^{r}=\widehat{e}_{t}-\widehat{P}_{t}=\gamma \widehat{S}_{t}$, which establishes a relationship between the real exchange rate and the terms of trade.

\subsection{Equilibrium}

In a symmetric equilibrium where all firms take identical decisions we have $P_{t}^{H}(i)=P_{t}^{H}, Y_{t}(i)=Y_{t}, X_{t}(i)=X_{t}, N_{t}(i)=N_{t} \forall i$. I assume that there are no government bonds. Furthermore, foreign investors do not hold assets

denominated in domestic currency. Domestic bonds are, therefore, in zero net supply:

\subsubsection{Goods Market}

Aggregate supply of output of the domestic good is:

$$
Y_{t}=\left[\int_{0}^{1} Y_{t}(i)^{\frac{\vartheta-1}{\vartheta}} d i\right]^{\vartheta \vartheta}
$$


Aggregate demand is :

$$
D_{t}=\left(\int_{0}^{1} X_{t}(i)^{\frac{\vartheta-1}{\vartheta}} d i\right)^{\frac{\vartheta}{\vartheta-1}}+\left[\int_{0}^{1} P_{t}^{H}(i)^{-\vartheta} d i\right]\left(\frac{1}{P_{t}^{H}}\right)^{-\vartheta}\left(\frac{P_{t}^{H}}{P_{t}}\right)^{-\rho}\left(C_{t}+C_{t}^{*}\right)
$$

In a equilibrium, $D_{t}=Y_{t}$. Therefore:

$$
\left[\int_{0}^{1} Y_{t}(i)^{\frac{\vartheta-1}{\vartheta}} d i\right]^{\vartheta \vartheta} \vartheta^{\vartheta-1}=X_{t}+\left[\int_{0}^{1} P_{t}^{H}(i)^{-\vartheta} d i\right]\left(\frac{1}{P_{t}^{H}}\right)^{-\vartheta}\left(\frac{P_{t}^{H}}{P_{t}}\right)^{-\rho}\left(C_{t}+C_{t}^{*}\right)
$$

Define the alternative price index $P^{H^{\prime}}=\left(\int_{0}^{1} P^{H}(i)^{-\vartheta} d i\right)^{-\frac{1}{\vartheta}}$ and the aggregate: $Y^{\prime}=\int_{0}^{1} Y(i) d i$, such that $Y=F(A, K, N)$, with $N=\int_{0}^{1} N(i) d i$ and $K=\int_{0}^{1} K(i) d i$. Notice, in particular, that $Y^{\prime}=\left(\frac{P^{H}}{P H^{\prime}}\right)^{\vartheta} Y$. Then 25 can be written, after imposing symmetry:

$$
\left[\left(\frac{P_{t}^{H}}{P_{t}}\right)^{-\rho}\left(C_{t}+C_{t}^{*}\right)\right]+X_{t}=\left(\frac{P_{t}^{H^{\prime}}}{P_{t}^{H}}\right)^{\vartheta} F(A, K, N)
$$

or, alternatively:

$$
Y_{t}=\left(\frac{P_{t}^{H^{\prime}}}{P_{t}^{H}}\right)^{-\vartheta}\left[C_{t}^{H}+C_{t}^{H^{*}}\right]+X_{t}
$$

\subsection{Exogenous Stochastic Processes}

The dynamics in the rest of the world is described by the following stochastic processes:

$$
\begin{gathered}
\left(1+i_{t}^{*}\right)=\left(1+i_{t-1}^{*}\right)^{\rho^{i^{*}}} \exp \left(\varepsilon_{t}^{i^{*}}\right) \\
Y_{t}^{*}=Y_{t-1}^{\rho^{y^{*}}} \exp \left(\varepsilon_{t}^{y^{*}}\right)
\end{gathered}
$$

Domestic exogenous variables evolve according to:

$$
\begin{aligned}
A_{t} & =A_{t-1}^{\rho^{a}} \exp \left(\varepsilon_{t}^{a}\right) \\
\zeta_{t} & =\zeta_{t-1}^{\rho^{\zeta}} \exp \left(\varepsilon_{t}^{\zeta}\right)
\end{aligned}
$$

with $E_{t} \varepsilon_{t+1}^{j}=0, E_{t} \varepsilon_{t+1}^{j} \varepsilon_{t+1}^{j^{\prime}}=\Sigma, j=y^{*}, i^{*}, a, \zeta$. 


\subsection{Monetary Policy and the Exchange Rate Regime}

The formulation of monetary policy by the domestic authority follows a generalized simple rule, in which deviations of (home) inflation, output and nominal exchange rate from their long-run target feed-back on short-run movements of the nominal interest rate ${ }^{10}$. This can be seen as an extension to the open economy of a tool that has proved to be quite useful in the description of monetary policy in the recent closed economy literature ${ }^{11}$.

The following equation describes the target for the nominal interest rate:

$$
\left(1+\overline{i_{t}}\right)=\left(\pi_{t}^{H}\right)^{\omega_{\pi}}\left(Y_{t}\right)^{\omega_{y}}\left(e_{t}\right)^{\left[\omega_{e} /\left(1-\omega_{e}\right)\right]}
$$

Notice that the monetary authorities react to contemporaneous movements of the nominal exchange rate (which is a jumpy forward-looking variable), and to contemporaneous values of inflation and output.

I follow Clarida-Galí-Gertler (1999), Rotemberg-Woodford (1998), and specify a model for the determination of the actual short-run interest rate that accounts for the desire of the monetary authorities to smooth changes in the interest rate:

$$
\left(1+i_{t}\right)=\left(1+\bar{i}_{t}\right)^{1-\chi}\left(\left(1+i_{t-1}\right)\right)^{1-\chi}
$$

By taking a log-linear approximation of 31 and 32 one obtains:

$$
\widehat{i}_{t}=\widetilde{\omega}_{\pi} \widehat{\pi}_{t}^{H}+\widetilde{\omega}_{y} \widehat{Y}_{t}^{H}+\widetilde{\omega}_{e} \widehat{e}_{t}+\chi \widehat{i}_{t-1}
$$

where a hat denotes the log deviation from respective steady state values, and $\widetilde{\omega}_{\pi} \equiv(1-\chi) \omega_{\pi}, \widetilde{\omega}_{y} \equiv(1-\chi) \omega_{y}, \widetilde{\omega}_{e} \equiv(1-\chi) \frac{\omega_{e}}{1-\omega_{e}}$.

The specification in (31) allows to approximate the systematic behavior of monetary policy under two polar regimes (floating and fixed exchange rates) as a function of the weight $\omega_{e}$ assigned to the movements of the nominal exchange about the parity.

In particular:

$$
\begin{gathered}
\omega_{e}=0 \Longrightarrow \text { floating exchange rate } \\
\omega_{e} \in(0,1] \Longrightarrow \text { managed-fixed exchange rate }
\end{gathered}
$$

A rule of this kind can describe how monetary policy is formulated in small open economies, and/or economies whose monetary policy setting is 
constrained by the participation to a fixed exchange rate regime. ClaridaGalí-Gertler(1998) estimate an interest rate rule for the so-called E3 countries (UK, France, Italy), and show that the inclusion of the German dayto-day rate is highly significant. The result confirms that the participation to the EMS has strongly affected the conduct of monetary policy in these countries. All this suggests that the setting of $\omega_{e}$ and $\omega_{\pi}$ may not be independent. The more stringent the constraint of the exchange rate regime (i.e., the closer $\omega_{e}$ to 1 ), the lower should be the leverage in conducting an independent inflation-targeting strategy (i.e., the lower $\left.\omega_{\pi}\right)^{12}$. In what follows, I therefore systematically test the sensitivity of the results to the simultaneous choice of $\omega_{e}$ and $\omega_{\pi}$.

\section{Model Parametrization.}

To solve the model I take a log-linear approximation of the equilibrium conditions about a balanced-trade zero-inflation steady state. The complete log-linearized model is described in appendix A. The model is parametrized as follows. Contemporaneous utility is specified as $U_{t}=\frac{1}{1-\sigma} C_{t}-\frac{1}{1+\nu} N_{t}^{1+\nu}$. I follow the business cycle literature, and set the discount rate $\beta=0.99$, the quarterly capital depreciation rate $\delta=.025$, the labor share $\alpha=1 / 3$, and the elasticity of labor supply $\nu=1$. I set the steady-state markup $\mu=1.2$, and the elasticity of the investment rate to the shadow price of capital $\eta=0.5$. The share of home-good consumption $\gamma$ is chosen such that the steady-state sum of exports and imports is roughly $40 \%$ of output. The elasticity of substitution between home and foreign consumption is set $\rho$ $=1.5$. As it is now common in the literature on the Calvo pricing technology, I let the probability of price non-adjustment $\phi$ be equal to 0.75 , which implies that the average frequency of price adjustment is four quarters. As to the monetary policy rule parameters, I set, as benchmark values, $\omega_{\pi}=1.5$, $\omega_{y}=0.5$ and $\chi=0.8$. In all the calibrations, I compare a setting in which $\omega_{\pi}$ is kept constant as $\omega_{e}$ changes, to one in which the increase in $\omega_{e}$ (by presumably implying a more limited leverage in the anti-inflationary strategy) is coupled by a proportional decrease in $\omega_{\pi}$. The outcome is not affected significantly, so only the results for the case of a constant $\omega_{\pi}$ are reported. Finally, the standard deviation of each shock is normalized to 1 , given the goal of characterizing only the relative volatility of different variables across exchange rate regimes. The persistence of each stochastic process is set to 0.9 . 


\section{The Volatility of the Real Exchange Rate: Nom- inal Rigidities and the Exchange Rate Regime.}

In this section, I try to identify whether some monotonic relationship actually exists in the model between the "proximity" (measured by $\omega_{e}$ ) to a managed-fixed exchange rate regime and the variability of the real exchange rate.

Figure 2 shows how the variability of some key variables changes as a function of $\omega_{e}$. I report the conditional standard deviation of the (logdifferences of the) series generated by a Monte Carlo simulation of the theoretical model. The results for the model with all the shocks are reported. As it stands clear, in moving from a pure floating to an increasingly fixed exchange rate regime, the standard deviation drops by about five times for the real exchange rate and roughly four times for the terms of trade. The volatility of the nominal exchange rate converges monotonically to zero. These numbers are in accordance with the evidence reported in Table 1. The decrease in volatility of the nominal exchange rate in moving towards a fixed rate regime is largely reflected in a lower volatility of both the real exchange rate and the terms of trade, with a contribution of the price ratio which barely changes. This picture clearly establishes a reduced-form relationship between the monetary policy feed-back rule and the volatility of the real exchange rate.

The contribution of each stochastic component.

It is natural to ask, at this point, to what extent this result depends upon the choice of the underlying stochastic force in the system. In Figure 3, I let the dynamics be driven only by one selected disturbance in each of the panel: technology, domestic demand, world interest rate and world demand. In all cases, the bulk of my result is unchanged. The relationship between exchange rate regime and real exchange rate volatility emerges independently of the source of the shock. In all cases the effect of a change in the nominal exchange rate regime is a drop in the volatility of the real exchange rate of about four times. The results above clearly favor an interpretation of the movements of the real exchange across regimes that is based on a systematic component, as opposed to one based on the prominent role of real stochastic disturbances.

\subsection{The Role of Nominal Rigidities}

What is exactly the contribution of nominal rigidities in qualitatively driving the results? To answer this question, I consider two extreme cases: floating 
$\left(\omega_{e}=0\right)$ vs. purely fixed exchange rates $\left(\omega_{e}=1\right)$. I then plot the ratio of the standard deviations of the real exchange rate under the two regimes as a function of the degree of nominal rigidities in the model, measured by $\phi$ (the probability of price non-adjustment). Figure 4 reports the ratio implied by the theoretical model for different experiments corresponding to different exogenous forces driving the dynamics. In every case it is clear that, as $\phi$ moves from 0 (fully flexible prices) to 1 (fully rigid prices), the volatility ratio of the real exchange rate under the two regimes increases substantially. Under fully flexible prices, the value of this ratio is always close to 1 , indicating that controlling for nominal rigidities eliminates any systematically different behavior of the real exchange rate under the two regimes, independently of the source of the shocks. As I move towards a higher degree of nominal rigidities and approach full rigidity of prices, the relative volatility of the real exchange rate increases between six and twelve times. An exception is the case in which technology shocks are the only driving force in the model: the increase in volatility in this case is not significant.

\section{Short Run Dynamics: Systematic Monetary Pol- icy and Transmission.}

This section describes the dynamics of the economy driven by selected stochastic innovations in the forcing processes. I show that a systematic regime for monetary policy is able to generate three results in line with the empirical literature for small open economies: i) A managed-fixed exchange rate regime systematically amplifies the short-run responses of the real exchange rate to different shocks. ii) The sign of the international transmission of monetary policy shocks can be positive. iii) A devaluation of the nominal exchange rate can be compatible with a rise in the domestic nominal interest rate.

Sims (1992), Grilli-Roubini (1995), Kim-Roubini (1997) report evidence for all the G7 countries (with the noticeable exception of the United States) of a puzzling contemporaneous depreciation of the nominal exchange rate in response to a domestic monetary contraction (i.e., an increase in the short-run nominal interest rate). This is in contrast with (some form of ) uncovered interest parity. Cushman-Zha (1997) argue that this puzzle derives from an inappropriate identification of monetary policy for small open economies, as the variation of the domestic interest rate can reflect a systematic response, through the central bank's reaction function, to innovations 
in foreign variables. Notice that this can hold in a regime of still floating exchange rates (e.g., Canada and the U.S), but it does a fortiori in the case of managed-fixed exchange rate systems like the $\mathrm{EMS}^{13}$.

This line of argument extends naturally to the evaluation of the sign of international transmission of monetary policy shocks. Consider an exogenous rise in the foreign nominal interest rate (i.e., a monetary contraction abroad). Under floating, at least one negative and one positive transmission channel can be generally recognized. The negative one works through the depreciation of the home currency, the increase in home exports and the rise in domestic output. The positive channel implies a fall in foreign aggregate demand and therefore in the export demand . In a regime of managed-fixed exchange rate, an additional (and potentially significant) positive channel works through the systematic response of the domestic interest rate to innovations in the foreign rate, affecting the volatility of the nominal exchange rate around the parity. Furman-Leahy (1996) find strong evidence of positive transmission in analyzing the Canada-U.S case, with the insight that this is not due to the economic transmission mechanism per se, but mainly to the systematic response of the Canadian authorities. Similarly, ClaridaGalí-Gertler (1998) show that the constraint of the central parity with the DM has represented a significant positive transmission channel from the German to the other EMS-countries' business cycle.

I show that the dynamic short-run behavior of my model is consistent with both the exchange rate anomaly and the evidence on the transmission sign. In particular, a monetary tightening abroad generates an expansion in domestic output under floating and a recession under a managed-fixed exchange rate regime. This is also in accordance with the general view that flexible exchange rates insulate countries from shocks originating abroad, but stresses the importance of a different mechanism in driving the results.

\section{A. Productivity Innovations}

Figure 5 displays the impulse response of selected variables to a $1 \%$ temporary innovation in total factor productivity under flexible (solid line) versus fixed exchange rates (dotted line). A technology shock determines a depreciation of the real exchange rate. This results from two simultaneous effects: the response of domestic prices and of the interest rate differential, which determines a depreciation of the nominal exchange rate. The fall in the nominal interest rate under floating is induced by the endogenous response of the monetary authorities. Accordingly, under fixed exchange rates, the domestic monetary authority perfectly correlates its own policy stance to the rest of the world. Overall, the depreciation of the nominal exchange rate under a float is translated onto the real exchange rate. The 
response, however, is much less pronounced in the case of fixed rates, due to the sluggishness in the adjustment of the price ratio. It is already possible to see the "Mussa effect" at work here. Notice that a regime floating rates amplifies the response of output. This effect depends both on the amplified response of investment and on the larger improvement in the trade balance (driven by the stronger real depreciation).

\section{B. Domestic Demand Innovations .}

Figure 6 displays the impulse responses to a demand shock. Appendix A shows that can be interpreted as a shock to a linearized forward-looking IS equation. The result is expansionary on output, and inflationary. This triggers a rise in the nominal interest rate, which causes both the nominal and the real exchange rate to appreciate. Again, under a float, the response of the real exchange rate is much larger than under fixed rates. Interestingly this kind of demand disturbance is able to generate a countercyclical response in the terms of trade in line with the empirical evidence, a result that money supply innovations are not able to accomplish (Eichenbaum-Evans (1995), Kim-Roubini (1997)). Net exports fall as a result of the appreciation in the real exchange rate, therefore displaying a countercyclical behavior, again in accordance with the empirical evidence reported in Backus-Kehoe-Kydland (1994).

C. Foreign Interest Rate Innovations .

In Figure 7, the impulse responses to an innovation in the world interest rate are shown. This shock can be interpreted as a monetary policy tightening abroad, as well as an unanticipated capital outflow for the domestic economy. The fall in the interest rate differential determines a devaluation of the nominal exchange rate under floating, due to the capital outflows, and a consequent improvement in the trade balance. Investment falls due to the reallocation of capital, but substantially only under fixed rates, because of the large rise in the real interest rate. The real exchange rate depreciates sharply under floating and only partially under fixed, again a result of the "Mussa effect".

\section{International Transmission}

The exercise above allows, in particular, to analyze the transmission of monetary shocks under different exchange rate regimes. Notice that I am considering an orthogonalized innovation in the foreign interest rate, which shuts down a positive channel of international transmission working through the fall in foreign aggregate demand and a consequent fall in exports. A tightening abroad clearly induces a positive transmission effect under managed exchange rates: both domestic output and inflation fall, whereas they both rise under floating. Crucial, again, is the different systematic behavior 
of monetary policy under the two regimes. Under managed-fixed exchange rates, the monetary authorities sharply increase the nominal interest rate to offset the fall in the return differential, causing a large increase in the real interest rate, which induces a deflationary effect on output. Conversely, under floating, nominal and real interest rates react much less sharply, and the beneficial effect of the improvement in the terms of trade and export demand is shifted onto output. This dynamics suggest that a crucial channel in the international transmission of monetary shocks can work through the spillovers from the monetary policy of one country directly to the monetary policy stance of another one. The effect is consistent with the empirical evidence (see Furman-Leahy (1996), Cushman-Zha (1997)).

Notice also that a devaluation of the real exchange rate - both under floating and fixed rates - is associated with a contemporaneous increase in the nominal interest rate. This effect might seem at odds with the standard open-macroeconomics textbook models. But this is actually in line with the empirical findings of Sims (1992) and Grilli-Roubini (1995) for all the G7 countries, with the exception of the U.S. The model suggests that this apparent puzzle can be due to an identification problem caused by the systematic response of the domestic monetary authorities of the small open economies. Controlling for this effect can reconcile with the standard theory the estimated response of the exchange rates to a monetary policy shock .

\section{Conclusions}

The formulation of monetary policy in terms of linear interest rate rules has attracted considerable attention in the recent macroeconomic literature. This tool has proved to be particularly useful in capturing both the unanticipated and, more importantly, the systematic role played by monetary policy over the business cycle. In this paper, I show that a generalization of this setting to the open economy allows an evaluation of a central topic in international macroeconomics: the short-run dynamic effects of a change in the nominal exchange rate regime. Along this avenue, I rationalize a series of controversial issues triggered by the change in regime, from the observed striking increase in volatility of the real exchange rate to the transmission of monetary policy shocks across countries. In a regime of managed exchange rates and/or coordinated monetary policies, the evidence of simultaneous devaluation of the exchange rate in the presence of a domestic monetary contraction can be consistent with the theory, and the sign of the international transmission of monetary policy shocks can be positive. Overall, the 
model conveys the key idea that the choice of the nominal exchange rate regime is not neutral for the short-run adjustments of international relative prices. 


\section{Appendix A. The log-linear equilibrium model}

Let lower case variables denote the percentage deviations from respective steady state values, and capital letters without time subscript actual steady state values. The equilibrium log-linear model can be described in terms of an aggregate demand and an aggregate supply block, along with the equations for the evolution of the state variables and the exogenous processes.

\section{A. Aggregate demand block.}

Log-linearization of the26, after noting that $\widehat{P}_{t}^{H^{\prime}}=\widehat{P}_{t}^{H}$, leads to:

$$
\widehat{Y}_{t}=\left(\frac{X}{Y}\right) \widehat{X}_{t}+\left(\frac{C^{H}}{Y}\right) \widehat{C}_{t}^{H}+\left(\frac{C^{H^{*}}}{Y}\right) \widehat{C}_{t}^{H^{*}}
$$

Aggregate consumption is a weighted average of consumption of domestic and foreign goods:

$$
\widehat{C}_{t}=\gamma \widehat{C}_{t}^{H}+(1-\gamma) \widehat{C}_{t}^{F}
$$

By combining 3 and 4 :

$$
\widehat{C}_{t}^{H}-\widehat{C}_{t}^{F}=\varrho \widehat{S}_{t}
$$

Under the assumption of certainty equivalence equation 9 becomes:

$$
\widehat{i}_{t}=\widehat{i}_{t}^{*}+E_{t}\left\{\widehat{e}_{t+1}\right\}-\widehat{e}_{t}
$$

which is a standard uncovered interest parity condition.

Equation 11 becomes:

$$
\widehat{C}_{t}^{H^{*}}=\varrho \widehat{S}_{t}+Y_{t}^{*}
$$

Log-linearization of 7 leads to:

$$
\widehat{C}_{t}=E_{t}\left\{\widehat{C}_{t+1}\right\}-\frac{1}{\sigma} \widehat{R}_{t+1}-\left(E_{t}\left\{\zeta_{t+1}\right\}-\zeta_{t}\right)
$$

Notice that the demand shock $\zeta_{t}$ can be interpreted as a shock to a forward looking IS equation.

Conditions 16 and 17 for efficiency in investment become:

$$
\begin{gathered}
\widehat{Q}_{t}=\frac{1}{\eta}\left(\widehat{X}_{t}-\widehat{K}_{t}\right) \\
\widehat{Q}_{t}=[1-\beta(1-\delta)] E_{t}\left\{\widehat{Z}_{t+1}\right\}+\beta(1-\delta) E_{t}\left\{\widehat{Q}_{t+1}\right\}+\left(\frac{\beta \delta}{\eta}\right) E_{t}\left\{\widehat{X}_{t+1}-\widehat{K}_{t+1}\right\}
\end{gathered}
$$


where $\eta \equiv-\left[\frac{\Phi^{\prime \prime}\left(\frac{X}{K}\right) \frac{X}{K}}{\Phi^{\prime}\left(\frac{X}{K}\right)}\right]>0$.

B. Aggregate Supply Block

Log-linearization of 19 and 20 lead to the following forward-looking Phillips-curve for domestic inflation:

$$
\widehat{\pi}_{t}^{H}=\beta E_{t}\left\{\widehat{\pi}_{t+1}^{H}\right\}+\left[\frac{(1-\phi)(1-\phi \beta)}{\phi}\right] \widehat{m c}_{t}
$$

where an equation for the determination of real marginal costs can be obtained from combining 6 and 13:

$$
\widehat{m c}_{t}=(1+v) \widehat{N}_{t}-\widehat{Y}_{t}+\sigma \widehat{C}_{t}+(1-\gamma) \widehat{S}_{t}
$$

Notice that a terms of trade depreciation (i.e., a rise in $\widehat{S}_{t}$ ) leads to a rise in real marginal costs (and therefore domestic inflation) through its effect on the product wage and on employment. In the case of a closed economy (i.e., $\gamma=1$ ) this exchange-rate channel on domestic inflation is absent.

C. Endogenous State Variables

The log-linearized capital accumulation equation reads:

$$
\widehat{K}_{t+1}=(1-\delta) \widehat{K}_{t}+\delta \widehat{X}_{t}
$$

D. Exogenous processes

$$
\begin{gathered}
\widehat{i}_{t}^{*}=\rho^{i *} \widehat{i}_{t-1}^{*}+\varepsilon_{t}^{i^{*}} \\
\widehat{Y}_{t}^{*}=\rho^{y^{*}} \widehat{Y}_{t-1}^{*}+\varepsilon_{t}^{y^{*}} \\
\widehat{A}_{t}^{*}=\rho^{a} \widehat{A}_{t-1}+\varepsilon_{t}^{a} \\
\widehat{\zeta}_{t}=\rho^{\zeta} \widehat{\zeta}_{t-1}+\varepsilon_{t}^{\zeta}
\end{gathered}
$$




\section{Notes}

${ }^{1}$ Mussa (1986).

${ }^{2}$ The size of the change in volatility is even higher for other episodes of regime change. This evidence is weaker in high-inflation developing countries (see Obstfeld (1997), Leiderman-Bufman (1996)). A possible explanation is that higher average inflation induces higher frequency of price adjustment, i.e., larger price flexibility.

${ }^{3}$ This is the theory postulated by Stockman in several papers (Stockman (1983, 1987, 1988)). According to this view real (e.g., preference) shocks affect the marginal rate of substitution between home and foreign goods and in turn the real and the nominal exchange rate. Therefore the feedback should work from the real to the nominal exchange rate whereas the opposite would be true in sticky-price models.

${ }^{4}$ This would be consistent with the traditional normative view (built on the Mundell-Fleming model) prescribing fixed exchange rates when monetary shocks are prevalent, and floating exchange rates when real shocks dominate.

${ }^{5}$ The example of Ireland is often reported as an argument against the endogeneity view (see Krugman (1989), Obstfeld (1997)). Before Ireland joined the EMS, its real exchange rate was much more closely correlated with that of the UK than with that of Germany, but after joining the EMS the rank in the correlation reversed. This is a clear example of an exogenous change in the nominal regime affecting the dynamic properties of the real exchange rate.

${ }^{6}$ See, among many others, Taylor (1993), Clarida-Galí-Gertler (1999), Rotemberg-Woodford (1998). Very recently a line of research on endogenous monetary policy in open economy has started to emerge (see references in Lane (1999)).

${ }^{7}$ For a survey on this other puzzle, see Rogoff (1996).

${ }^{8}$ See Huizinga (1987), Campbell-Clarida (1987), Meese-Rogoff (1983). Flood-Rose (1995) argue, more generally, that short-run movements of the real exchange rate seem simply difficult to relate to macroeconomic fundamentals

${ }^{9}$ More recently, Rogers (1999) makes a stronger claim in favor of the role of monetary shocks.

${ }^{10} \mathrm{An}$ issue emerges here as to whether the monetary authority should be targeting CPI inflation as opposed to domestic inflation. This point is extensively discussed in Svensson (2000). I abstract from these issues here.

${ }^{11}$ See, among others, Taylor (1996), Clarida-Galí-Gertler (1998), Rotemberg- 
Woodford (1998).

${ }^{12}$ Clarida-Galí-Gertler (1998), in fact, show that the coefficient on (expected) inflation reduces significantly when the German interest rate is added as a regressor.

${ }^{13}$ See Clarida-Galí-Gertler (1998) for the empirical relevance of this point in the European "satellites". 


\section{References}

[1] Backus, David, Patrick J.Kehoe and Finn E.Kydland, 1992. International Real Business Cycles. Journal of Political Economy 101: 745-775.

[2] , 1994. Dynamics of the Trade Balance and the Terms of Trade:The J-Curve?. American Economic Review 84: 84-103.

[3] - International Business Cycles: Theory and Evidence, 1995, in Cooley, T. (Ed.), Frontiers of Business Cycle Research, Princeton University Press.

[4] Beaudry, Paul and M.B. Devereux, 1995. Money and the Real Exchange Rate with Sticky Prices and Increasing Returns. Carnegie-Rochester Conference Series on Public Policy 43, 55-101.

[5] Betts, Caroline and M.B. Devereux, 2000. Exchange Rate Dynamics in a Model with Pricing-to-Market. Journal of International Economics, 50, 215-244.

[6] Calvo, Guillermo, 1983. Staggered Prices in a Utility Maximizing Framework. Journal of Monetary Economics 12, 383-398.

[7] Campbell, J and R. Clarida, 1987. The Dollar and the Real Interest Rate. An Empirical Investigation. Carnegie-Rochester Conference Series on Public Policy, 27: 103-140.

[8] Chari, V.V, Patrick J.Kehoe and Ellen R. Mc Grattan, 2000. Can Sticky Price Models Generate Volatile and Persistent Real Exchange Rates? NBER Working Paper 7869.

[9] Clarida, Richard, Jordi Galí and Mark Gertler, 1998. Monetary Policy Rules in Practice. Some International Evidence. European Economic Review ,42, 1033-1068.

[10] - 1999. The Science of Monetary Policy. Journal of Economic Literature, forthcoming.

[11] and Jordi Galí, 1994. Sources of Real Exchange Rate Fluctuations: How Important are Nominal Shocks ? CarnegieRochester Conference Series on Public Policy 41, 1-56.

[12] Cushman, David O. and Tao Zha,1997. Identifying Monetary Policy in a Small Open Economy under Flexible Exchange Rates. Journal of Monetary Economics 39, 433-448. 
[13] Eichenbaum, Martin and Charles Evans, 1995. Some Empirical Evidence on the Effects of Shocks to Monetary Policy on Exchange Rates. Quarterly Journal of Economics 110, 975-1009.

[14] Flood, Robert P., and Andrew K.Rose, 1995. Fixing Exchange Rates: A Virtual Quest for Fundamentals. Journal of Monetary Economics 36, $3-37$.

[15] Furman, Jason and John Leahy, 1996. The International Transmission of Monetary Policy: Evidence from the United States to Canada", Harvard Institute of Economic Research Discussion Papers.

[16] Grilli, Vittorio and N. Roubini, 1995. Liquidity and Exchange Rates: Puzzling Evidence from G7 Countries. Working Paper Yale University.

[17] Hau, Harald, 1999. Exchange Rate Determination: The Role of Factor Price Rigidities and Nontradeables. Journal of International Economics, forthcoming.

[18] Huizinga, John, 1987. An Empirical Investigation of the Long-Run Behavior of Real Exchange Rates", Carnegie-Rochester Conference Series on Public Policy, 27: 149-215.

[19] Kim, Soyoung and Nouriel Roubini, 1997. Liquidity and Exchange Rates in the G7 Countries: Evidence from Identified VARs", Mimeograph.

[20] Kollmann, Robert, 1997. The Exchange Rate in a Dynamic-Optimizing Current Account Model with Nominal Rigidities: a Quantitative Investigation. International Monetary Fund Working Paper 97/7.

[21] Krugman, Paul, 1989. Exchange Rate Instability, MIT Press.

[22] Lane, Philip, 2000. The New Open Economy Macroeconomics: a Survey. Journal of International Economics, forthcoming.

[23] Leiderman, L. and G. Bufman, 1996. Searching for Nominal Anchors in Shock-Prone Economies in the 1990s: Inflation Targets and Exchange Rate Bands, in R. Hausmann and H. Reisen (Eds), Securing Stability and Growth in Latin America: Policy Issues and Prospects for ShockProne Economies, OECD Paris.

[24] Meese, Richard A. and Kenneth Rogoff, 1983. Empirical Exchange Rate Models of the Seventies: Do they Fit out of sample ? Journal of International Economics 14, 3-24. 
[25] Mussa, Micheal, 1996. Nominal Exchange Regimes and the Behavior of Real Exchange Rates: Evidence and Implications", Carnegie-Rochester Conference Series on Public Policy 25, 117-214.

[26] Obstfeld, Maurice, 1995. International Currency Experience: New Lessons and Lessons Relearned", Brookings Papers on Economic Activity.

[27] , 1997. Open-Economy Macroeconomics: Developments in Theory and Policy", NBER Working Paper no. 6319.

[28] Rogers, John H, 1999. Monetary Shocks and Real Exchange Rates. Journal of International Economics, 49, 269-288.

[29] Rogoff Kenneth, 1996. The Purchasing Power Parity Puzzle. Journal of Economic Literature 34, 647-688.

[30] Rotemberg, Julio J. and Micheal Woodford, 1998. Interest Rate Rules in an Estimated Sticky Price Model, in J.B Taylor (ed.), Monetary Policy Rules, Chicago: University of Chicago Press for NBER.

[31] Sims, C.A, 1992. Interpreting the Macroeconomic Time Series Facts: the Effects of Monetary Policy. European Economic Review 36, 9751000 .

[32] Stockman, Alan C., 1983. Real Exchange Rates under Alternative Nominal Exchange Rate Systems. Journal of International Money and Finance, 147-166.

[33] - 1987. The Equilibrium Approach to Exchange Rates", Federal Reserve Bank of Richmond Economic Review 73 (2): 12-30.

[34] - 1988. Real Exchange Rate Variability under Pegged and Floating Nominal Exchange Rate Systems: an Equilibrium Theory", Carnegie-Rochester Conference Series on Public Policy 29, 259-294.

[35] Taylor, John B., 1993. Discretion versus Policy Rules in Practice. Carnegie-Rochester Series on Public Policy 39, 195-214.

[36] Svensson Lars E, 2000. Open-Economy Inflation Targeting. Journal of International Economics 50, 155-183.

[37] Yun, Tack, 1996. Nominal Price Rigidity, Money Supply Endogeneity, and the Business Cycles. Journal of Monetary Economics, 37. 345-370. 


\section{Nominal vs. Real Exchange Rate}
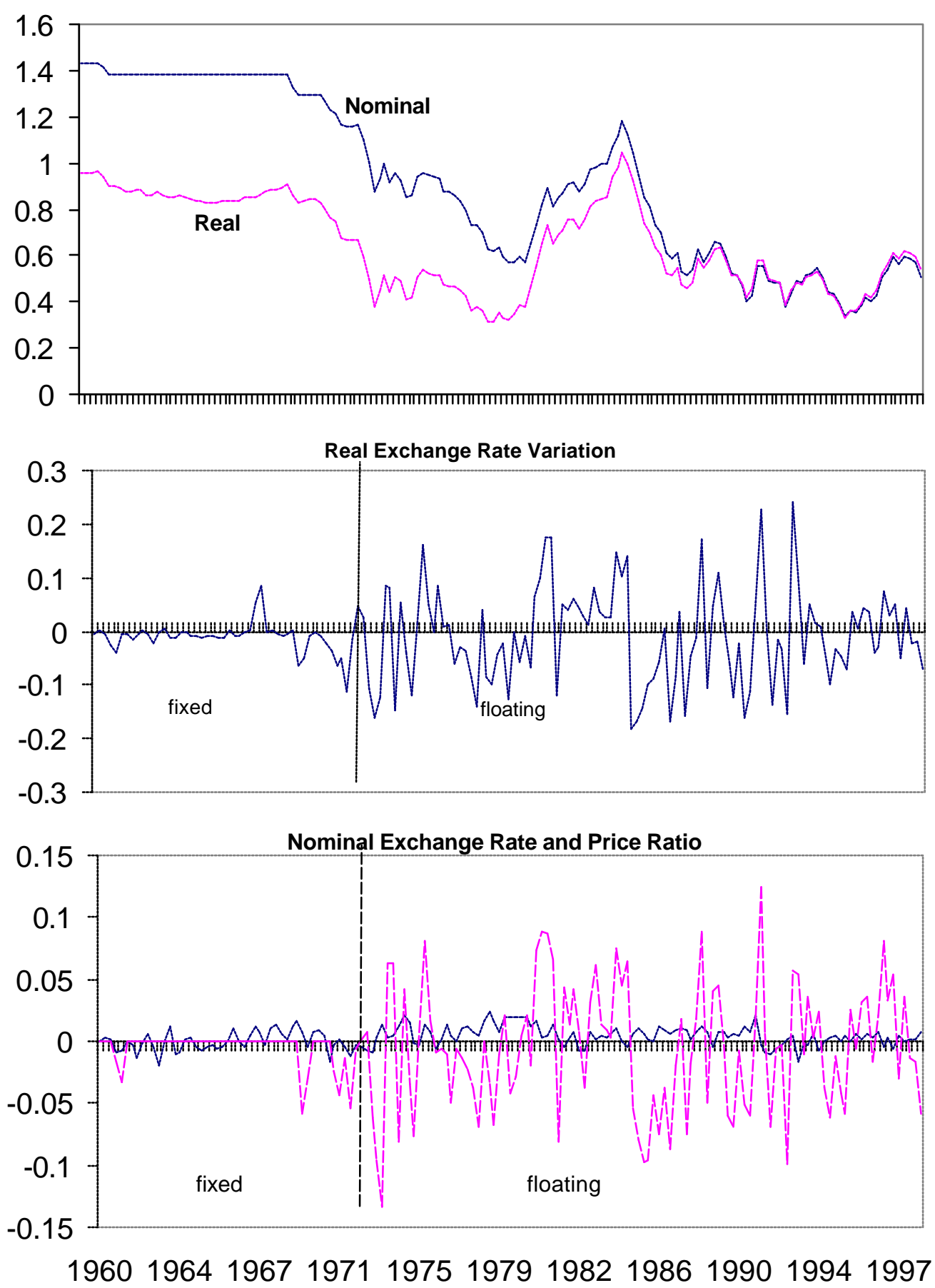

Figure 1. Germany/U.S. Exchange Rat (Data are quarterly log-levels (top) and log-differences (medium/bottom). In the bottom panel the solid line is the price level ratio and the dashed line is the nominal exchange rate. 


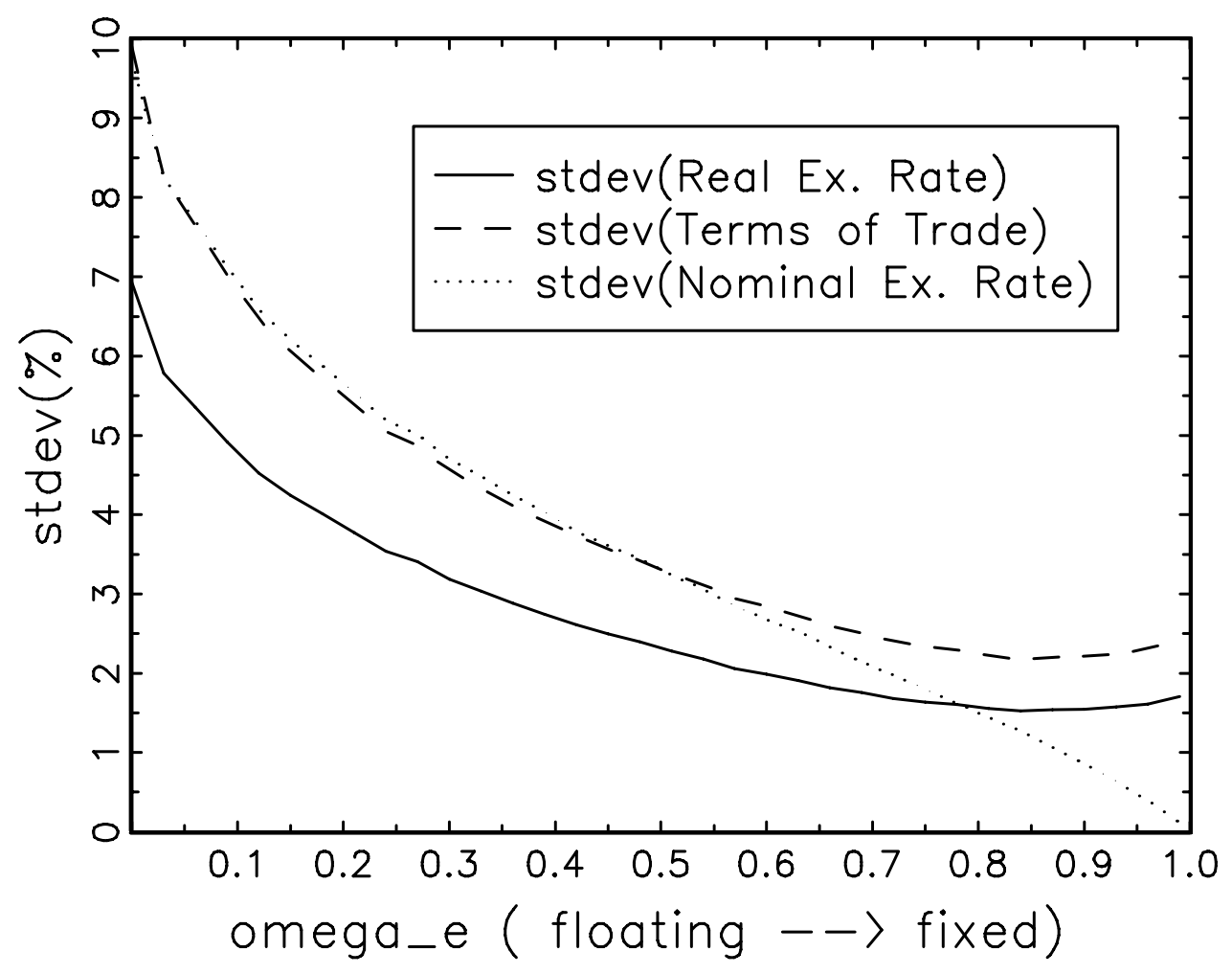

Figure 2: Volatility of the Exchange Rates and the Terms of Trade in moving from Floating to Fixed Rates (conditional on all shocks). 
technology shocks

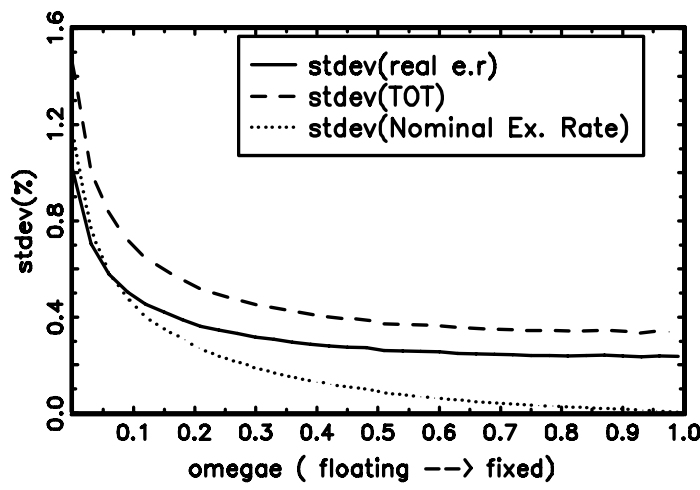

world i.rate shocks

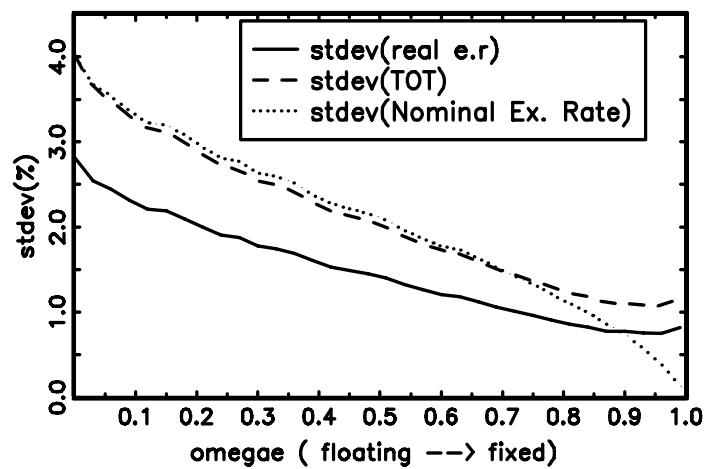

demand shocks

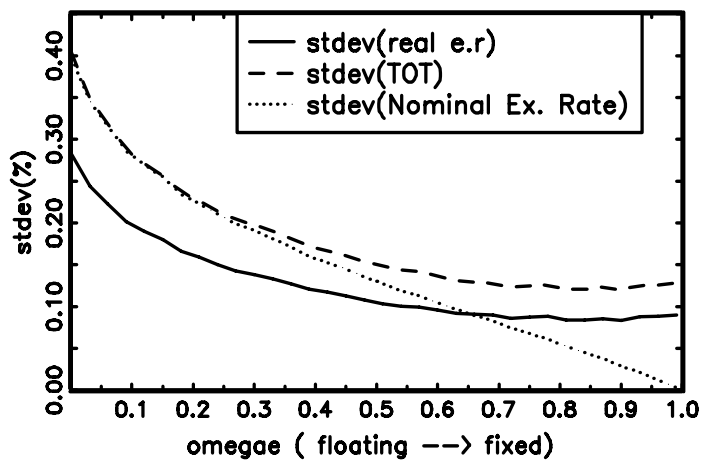

world demand shocks

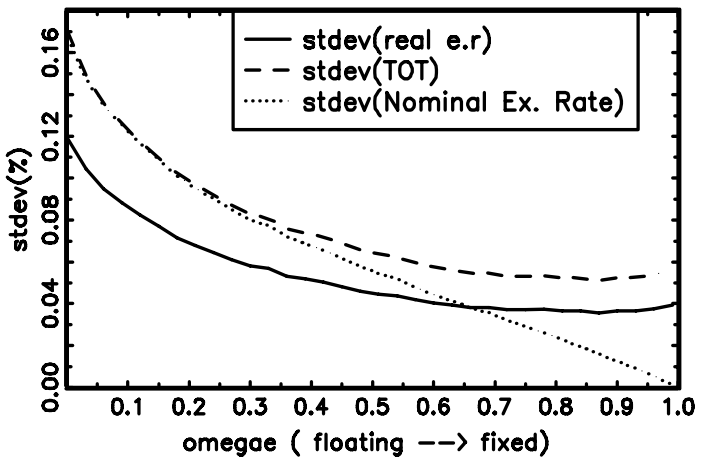

Figure 3: Volatility of the Exchange Rates and the Terms of Trade in moving from Floating to Fixed Rates (conditional on a single shock respectively). 


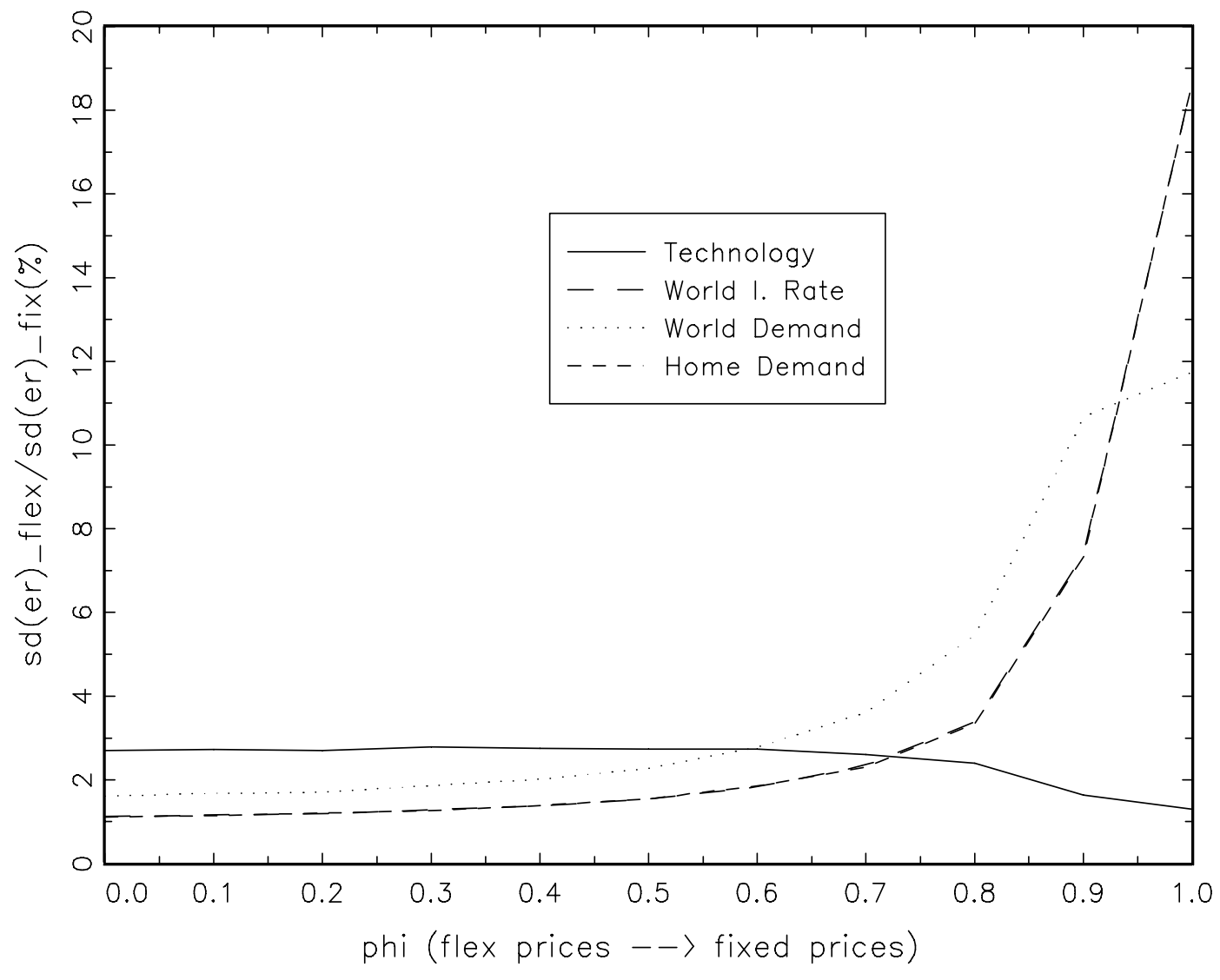

Figure 4: Volatility Ratio of the Real Exchange Rate and Degree of Price Stickiness. Entries are the ratios of the standard deviation under floating to the one under fixed rates. 
Output

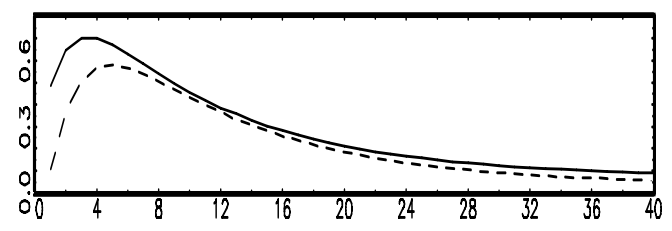

Home Inflation
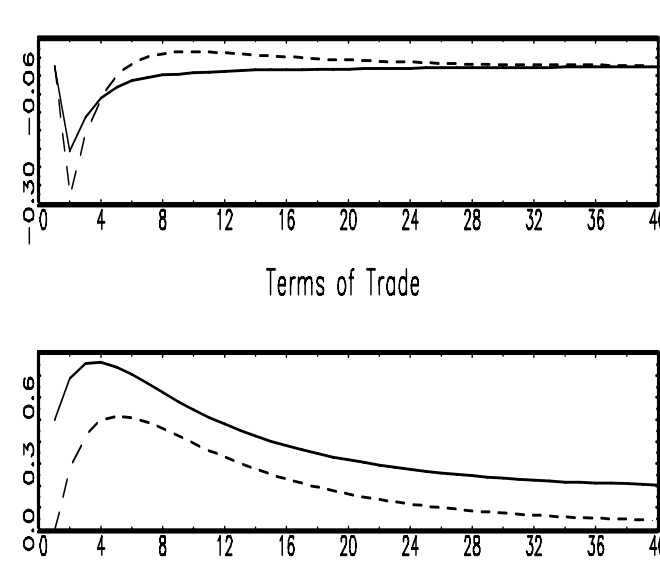

Nominal I.Rate

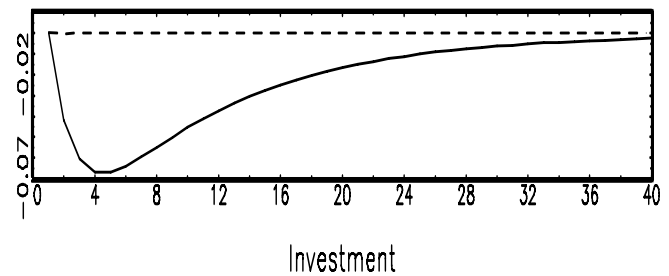

Investment

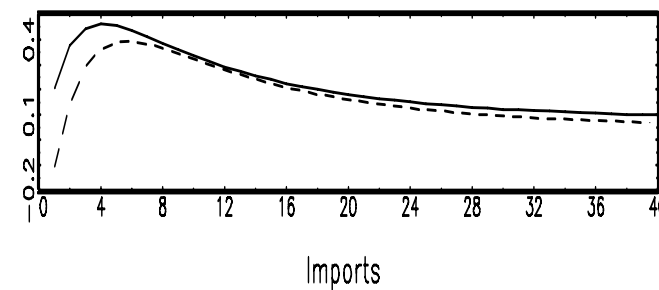

Imports
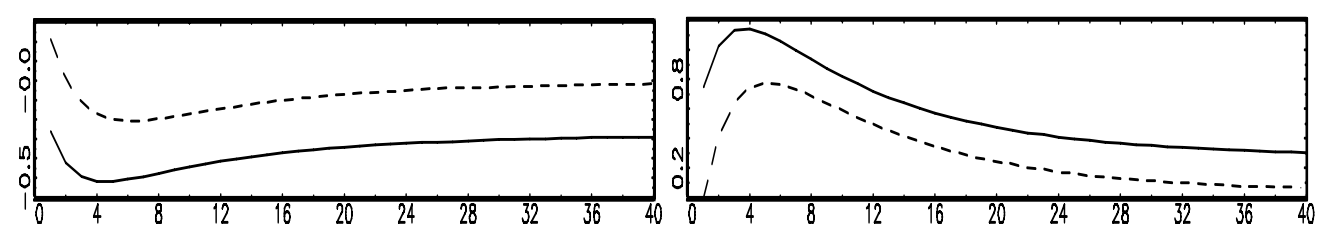

Consumption
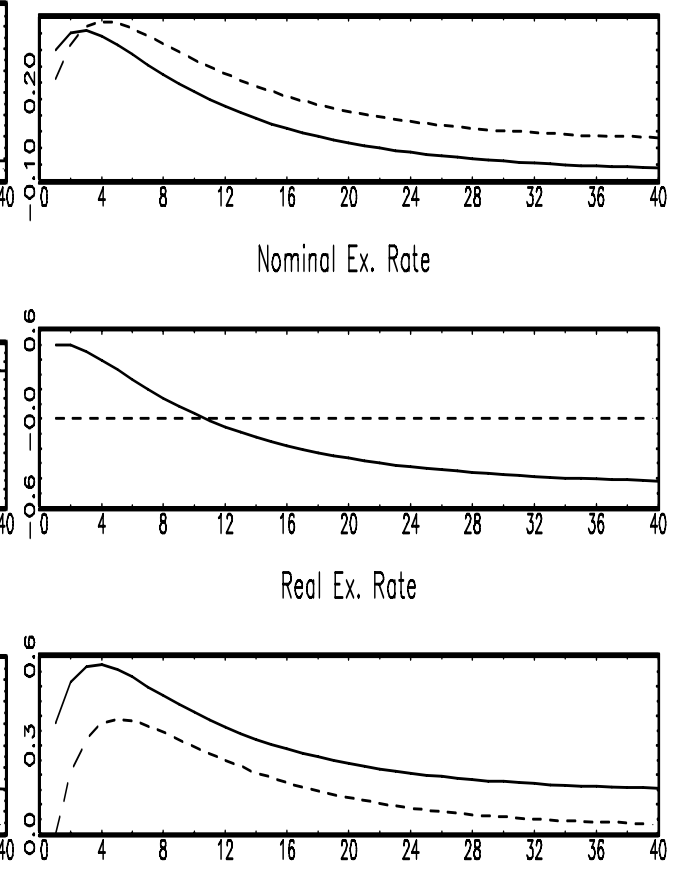

Real I.Rate_ CPI bosed
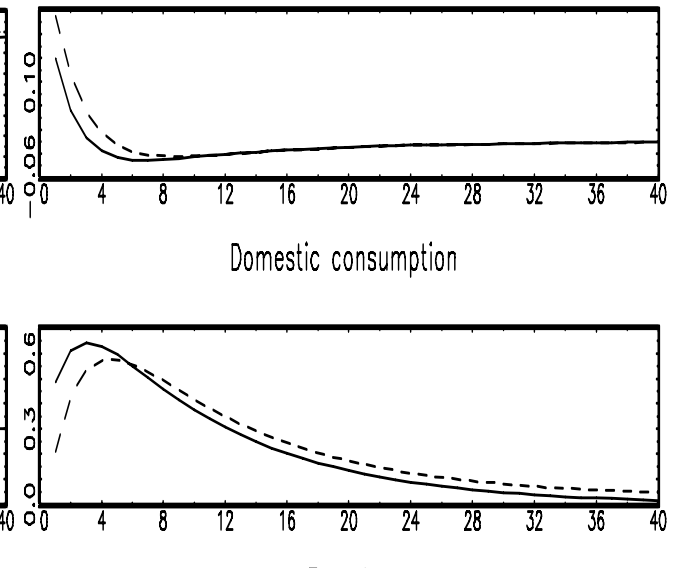

Exports

Figure 5: Impulse Responses to a Domestic Productivity Shock. Solid line: Flexible Exchange Rates. Dotted Line: Fixed Exchange Rates. 
Output

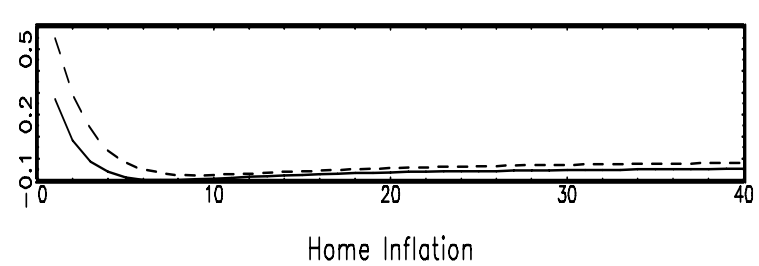

Home Inflation

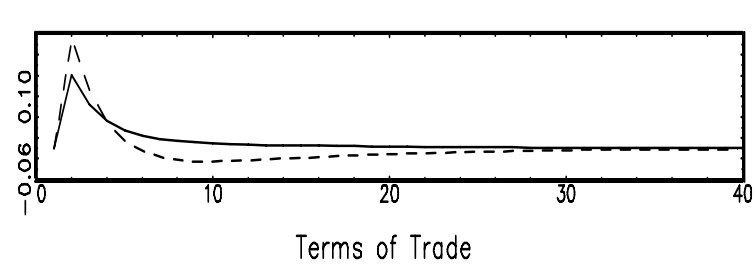

0

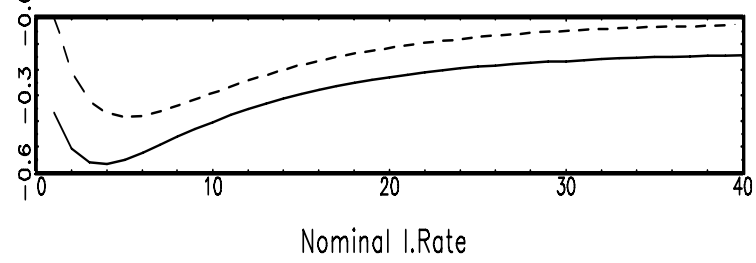

Nominal I.Rate
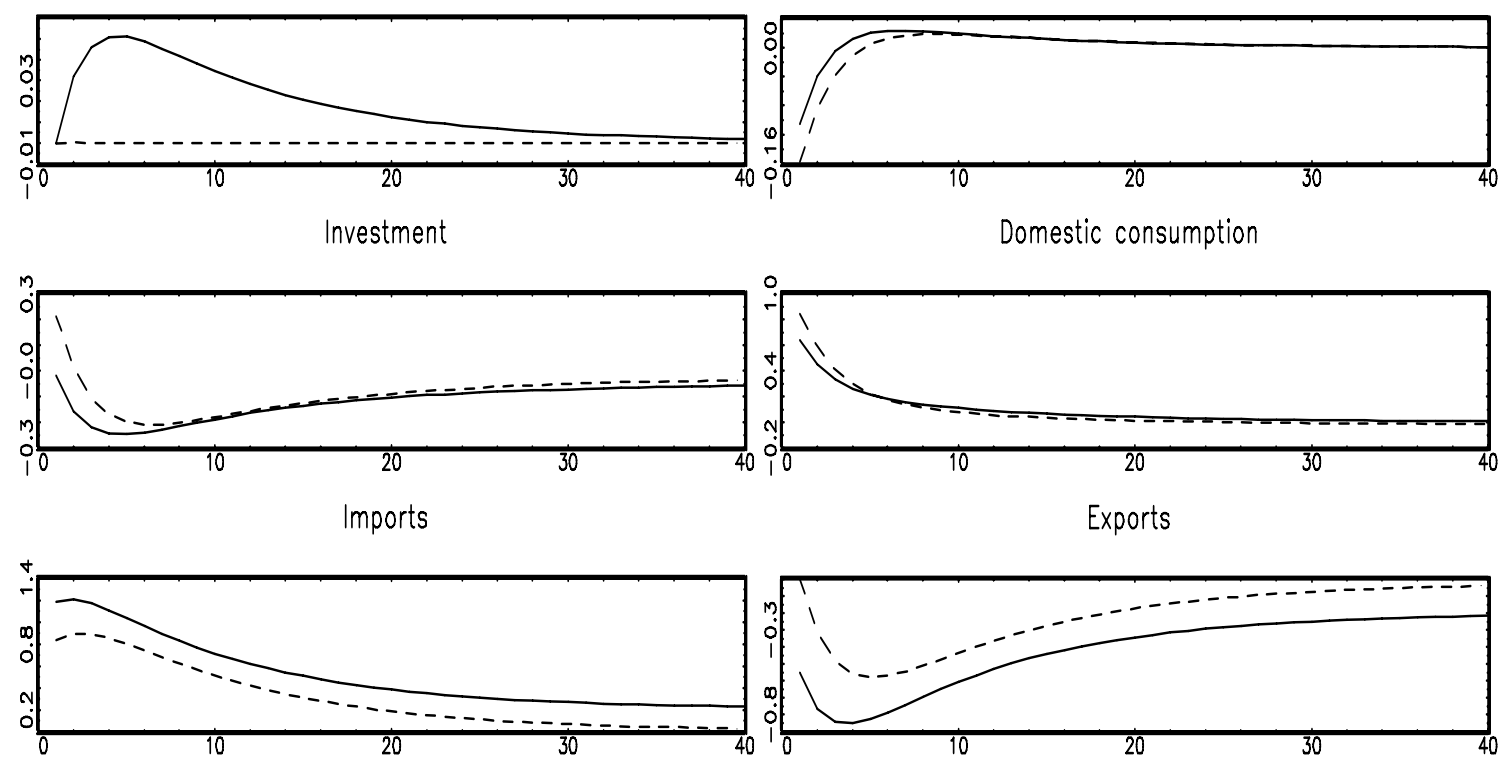

Figure 6: Impulse Responses to a Domestic Demand Shock. Solid line: Flexible Exchange Rates. Dotted Line: Fixed Exchange Rates. 
Output

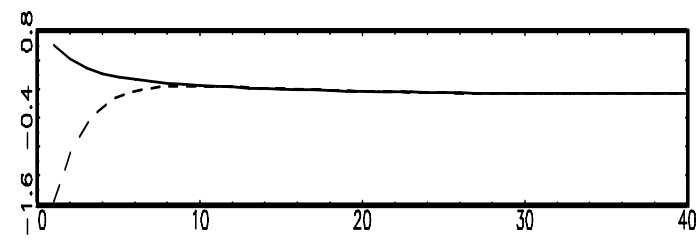

Home Inflation
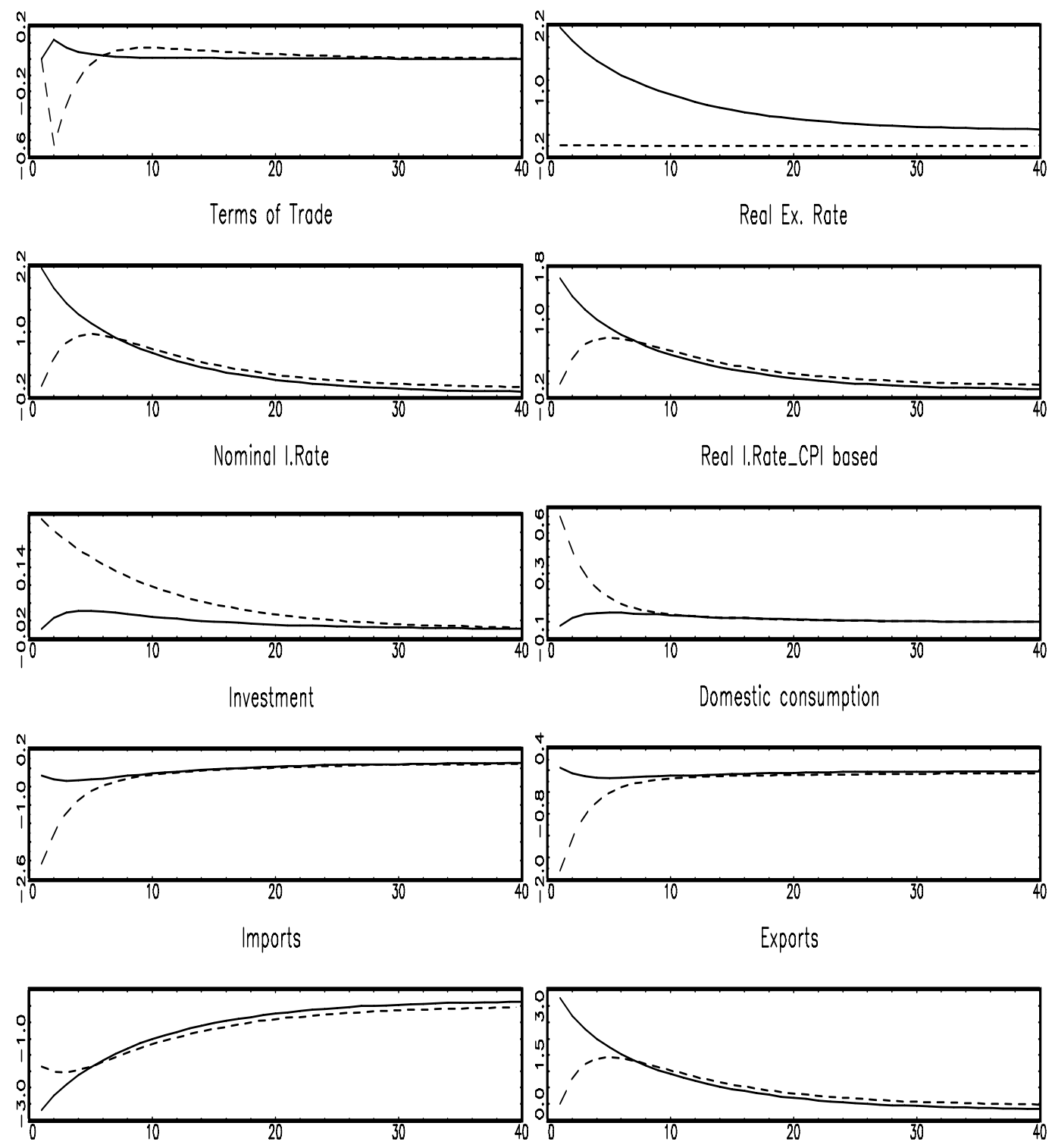

Figure 7: Impulse Responses to a World Interest Rate Shock. Solid line: Flexible Exchange Rates. Dotted Line: Fixed Exchange Rates.
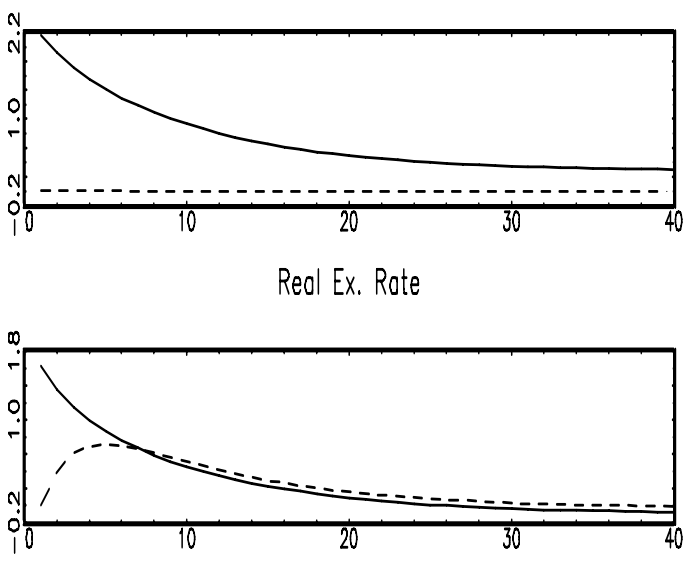

Real I.Rote_CPI bosed

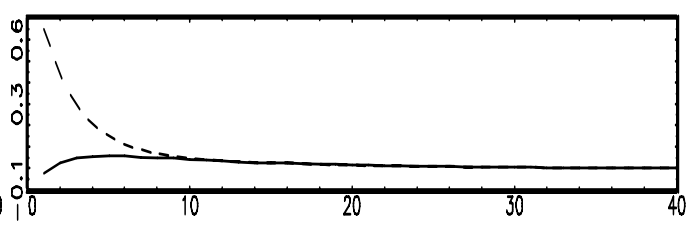

Domestic consumption

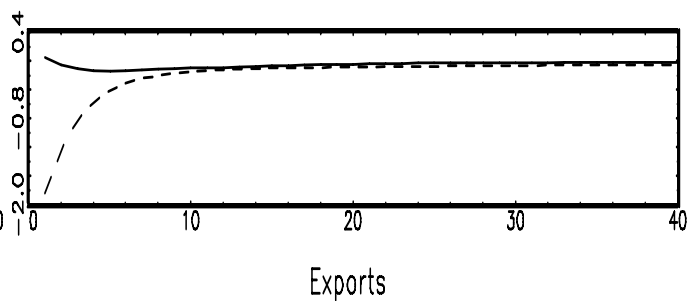

